\title{
Effects of Secondary Chamber on Gas Yield by Pre-Vacuum Chamber Pyrolysis of Rubber Wood
}

\author{
Hiroki Homma ${ }^{1 *}$, Hiroomi Homma², Sihar Siahaan ${ }^{3}$ \\ ${ }^{1}$ Department of Mechanical Engineering, Matsue College, National Institute of Technology, Matsue, Japan \\ ${ }^{2}$ Department of Mechanical Engineering, University of North Sumatera, Medan, Indonesia \\ ${ }^{3}$ Graduate School of Mechanical Engineering, University of North Sumatera, Medan, Indonesia \\ Email: ^homma@be.to
}

How to cite this paper: Homma, H., Homma, H. and Siahaan, S. (2017) Effects of Secondary Chamber on Gas Yield by Pre-Vacuum Chamber Pyrolysis of Rubber Wood. Journal of Sustainable Bioenergy Systems, 7, 1-13.

https://doi.org/10.4236/jsbs.2017.71001

Received: January 5, 2017

Accepted: February 10, 2017

Published: February 13, 2017

Copyright (c) 2017 by authors and Scientific Research Publishing Inc. This work is licensed under the Creative Commons Attribution International License (CC BY 4.0).

http://creativecommons.org/licenses/by/4.0/

\begin{abstract}
Global warming awareness criticizes further usage of fossil fuels and insists promotion of renewable energy usage. Additionally, many people in rural areas of developing countries cannot access electricity. To solve this sort of energy crisis including global warming, current authors developed a proto-type of a pyrolysis plant equipped with a pre-vacuum chamber, which can be used to produce combustible gases for an engine generator in rural areas where people cannot access electricity. The plant is simple and easily maintained in consideration of special conditions that a rural area can receive very few maintenance service, technical assistance, and supply of spare parts. However, gas yield obtained by the proto-type of plant was around $20 \mathrm{wt} \%$ of feedstock. One way to enhance gas yield from this proto-type of plant is to utilize reaction of secondary tar cracking. This research work aims to examine possibility of gas yield enhancement keeping a simple structure of the proto-type of plant and using a simple technique of secondary tar cracking. Two tar cracking methods are examined: one is homogeneous tar cracking and the other is heterogeneous tar cracking using catalysis. In the homogeneous tar cracking, pyrolysis gases must be heated up to $650^{\circ} \mathrm{C}$ to $700^{\circ} \mathrm{C}$ and in the heterogeneous tar cracking, wood char is used as catalysis, because wood char is byproduct of pyrolysis. It is concluded that the homogeneous tar cracking is quite unlikely in the secondary chamber, but on the other hand, heterogeneous tar cracking using wood char can produce $30 \mathrm{wt} \%$ of gas yield from $1 \mathrm{~kg}$ of feedstock.
\end{abstract}

\section{Keywords}

Secondary Chamber, Pre-Vacuum Chamber, Rubber Wood, Secondary Tar Cracking, Gas Yield, Gas Component 


\section{Introduction}

United Nations Framework on Climate Change, 21st Conference of Parties (COP21), declared the statement that the global common and long term target is to suppress average temperature raise under 2 degree, even 1.5 degree from the average temperature before industrial revolution era [1]. All the participant countries must definitely declare their concrete targets. They must make serious efforts to reduce carbon dioxide emission resulting global warming. On the other hand, International Energy Agency (IEA) reports that emission amount of carbon dioxide gas in 2015 was 32.1 gigaton, the same as that in 2014 , even though three percent of economic growth in the world was achieved in 2015 and a main contributor to the suppression of carbon dioxide gas emission is considered utilization of renewable energy for new electric power plants [2]. In developing countries, supply of electricity does not match with the demand. They still use fossil fuel like coal for power generation plants, for instance China and Indonesia. The study by IAE also indicated that more than one billion people in the world cannot access electricity [3]. Such people live in rural areas and are not usually covered by grids of power supply.

Off grid of power supply is a feasible way to enhance electrification in the rural areas. There are several technologies for the off-grid power supply, such as micro-hydraulic power, solar photovoltaic cell, and biomass pyrolysis or gasification. They have, however, advantages and substantial disadvantages. For example, the micro-hydraulic power and solar photovoltaic cell panels need expressive initial investment cost, and biomass gasification needs briskets of fuel and feedstock biomass. For instance, a micro-hydraulic power plant costs around 30,000 US $\$$ for $2 \mathrm{~kW}$, and solar photovoltaic cell costs 10,000 US\$ for $2 \mathrm{~kW}$. Rural area people, who cannot have enough money for initial investment, and frequent maintenance service, need low cost and less maintenance equipment for power generation. Pyrolysis is a rather old technique, but rather simple and of less maintenance.

Considering economy of rural area people, the current authors developed a proto-type of plant to produce pyrolysis gas that can be used for fuel of an engine generator and reported its basic performance [4] [5]. Gas production of this plant was less than $30 \%$ of feedstock. Usually, plant performance degrades gradually as usage period. Slow pyrolysis process undergoing in this plant produces gas yield as much as $10 \%$ to $35 \%$ of feedstock [6]. Gas yield from wood pyrolysis increases when pyrolysis temperature increases from $500^{\circ} \mathrm{C}$ to $900^{\circ} \mathrm{C}$ [7]. The gas yield was obtained as much as $50 \mathrm{wt} \%$ of the feedstock at $900^{\circ} \mathrm{C}$. On the other hand, other researchers obtained gas yield as much as more than $65 \mathrm{wt} \%$ of the feedstock at pyrolysis reactor temperature beyond $800^{\circ} \mathrm{C}$ [8]. The increase of gas yield is considered as a result from secondary tar cracking.

Several researches on secondary tar cracking in wood pyrolysis have been carried out [9]-[21]. There are two types of secondary tar cracking, namely homogeneous and heterogeneous cracking. Only temperature takes part in the homogeneous tar cracking, while temperature and catalyst take part in the heterogeneous tar cracking. 
In homogeneous tar cracking, secondary tar cracking is initiated at temperature of more than $600^{\circ} \mathrm{C}$, and the cracking reaction is promoted with the temperature rise [13]. Then, the primary tar from wood pyrolysis is completely converted to secondary tar, light molecular tar and gases. Fast pyrolysis utilizes homogeneous tar cracking to produce high volume of gases.

On the other hand, in heterogeneous tar cracking, not only temperature, but also catalyst takes part in tar cracking. The cracking reaction takes place near catalyst and it is called heterogeneous one in contrast to homogeneous one, which takes place in whole reactor. Many researches on catalyst effectiveness were carried out for Fe based catalyst [16], Ni based catalyst [17] [18], Pd [19], zeolite [20] and char [21]. The main purpose of catalyst is promotion of tar cracking reaction to remove tar from syngas completely. Another effect of catalyst is to down temperature for tar cracking. In homogeneous tar cracking [13], the primary tar cracking was initiated above $600^{\circ} \mathrm{C}$. If palladium was used for tar cracking catalyst [19], primary tar conversion reached around $50 \%$ at $500^{\circ} \mathrm{C}$ of catalyst temperature, $80 \%$ at $600^{\circ} \mathrm{C}$, and $92 \%$ at $700^{\circ} \mathrm{C}$. In this experiment, syngas was heated at $300^{\circ} \mathrm{C}$. As mentioned in the research [21], char can be surely used for a catalyst of tar cracking, and it is cheaper than other commercial catalysts. In addition, catalytic temperature of char is around $100^{\circ} \mathrm{C}$ lower than that of metallic catalysts, such as Platinum, $\mathrm{Pt}$ and Alumina, $\mathrm{Al}_{2} \mathrm{O}_{3}$.

This work aims at gas yield enhancement in the proto-type plant of pre-vacuum chamber pyrolysis, which has been developed to supply electricity to people living in isolated rural areas. Therefore, feasibility on two ways of secondary tar cracking, homogeneous one and catalytic one is examined. Catalyst to be used is char, because char is cheap and continuously produced by pyrolysis of wood, namely self-supplied. In the previous experiment [4], temperature at top of prevacuum chamber where small rubber wood pieces underwent thermochemical reaction, was around $400^{\circ} \mathrm{C}$. In this work, a secondary chamber is designed and constructed for secondary tar cracking after the pre-vacuum chamber and pyrolysis gas including tar vapor is heated more than $600^{\circ} \mathrm{C}$. In the proto-type plant, a wood stove is used for a furnace. Precise temperature control in the secondary chamber is substantially impossible. In such situation, this work attempts secondary tar cracking under less controlled temperature, namely large fluctuation of temperature, and effectiveness of the secondary chamber is discussed.

\section{Experimental Procedure for Enhancement of Gas Yield}

To increase combustible gas yield, a secondary tar cracking reaction is introduced to the proto-type plant equipped with a pre-vacuum chamber for rubber wood pyrolysis, which has been developed for self-supply of electricity to rural people [4]. In this work, the secondary tar cracking undergoes in the secondary chamber heated by exhaust gas from the furnace.

\subsection{Apparatus}

A secondary chamber is designed and constructed to heat pyrolysis gas from the 
pre-vacuum chamber up to more than $600^{\circ} \mathrm{C}$ and placed between the pre-vacuum chamber and the tar trap. A schematic diagram of the experimental apparatus is shown in Figure 1. Except the secondary chamber, the apparatus is the same as one used in the previous experiment [4]. Pyrolysis gas flow is also indicated by arrows in the figure. Rubber wood pieces are decomposed to pyrolysis gas including tar vapor in the pre-vacuum chamber and the pyrolysis gas flows out there and enter a secondary chamber from the bottom. The secondary chamber consists of a steel triple tube. The outermost tube is made of a steel pipe, $195 \mathrm{~mm}$ in outer diameter, $5 \mathrm{~mm}$ in wall thickness, and $845 \mathrm{~mm}$ in height. The middle tube is made of a stainless pipe of JIS $10 \mathrm{k}-80 \mathrm{~A}$. The center tube is also made of a stainless pipe, $40 \mathrm{~mm}$ in outer diameter, and $2 \mathrm{~mm}$ in wall thickness. The exhaust gas flows in the center tube and the outermost tube, and the pyrolysis gas flows in the middle tube. The center and outermost tubes are heated by exhaust gas, namely combustion gas of fuel wood pieces. Temperature of exhaust gas is monitored by a thermo-couple at a position $50 \mathrm{~mm}$ before the secondary chamber inlet. The end of the thermo-couple is positioned at the center of the chimney. Char is used for catalyst of secondary tar cracking. When the catalyst is used in experiments, char is put in the basket and placed at the middle height in the middle tube. Char is broken into small pieces, around $10 \mathrm{~mm} \mathrm{cu}-$ bic. Total mass of the char is $80 \mathrm{~g}$. Outermost surface of the secondary chamber is covered with thermal insulating band to prevent exhaust gas temperature from drop.

\subsection{Experimental Conditions and Method}

\subsubsection{Feedstock and Char of Catalyst}

Three kinds of experiments are carried out to examine effectiveness of the secondary chamber for homogeneous and heterogeneous, catalytic, tar cracking. The experimental conditions are summarized in Table 1. In experiment of no tar cracking, the secondary chamber is removed from the experimental apparatus to obtain the reference data. Feedstock is rubber wood pieces that are wood

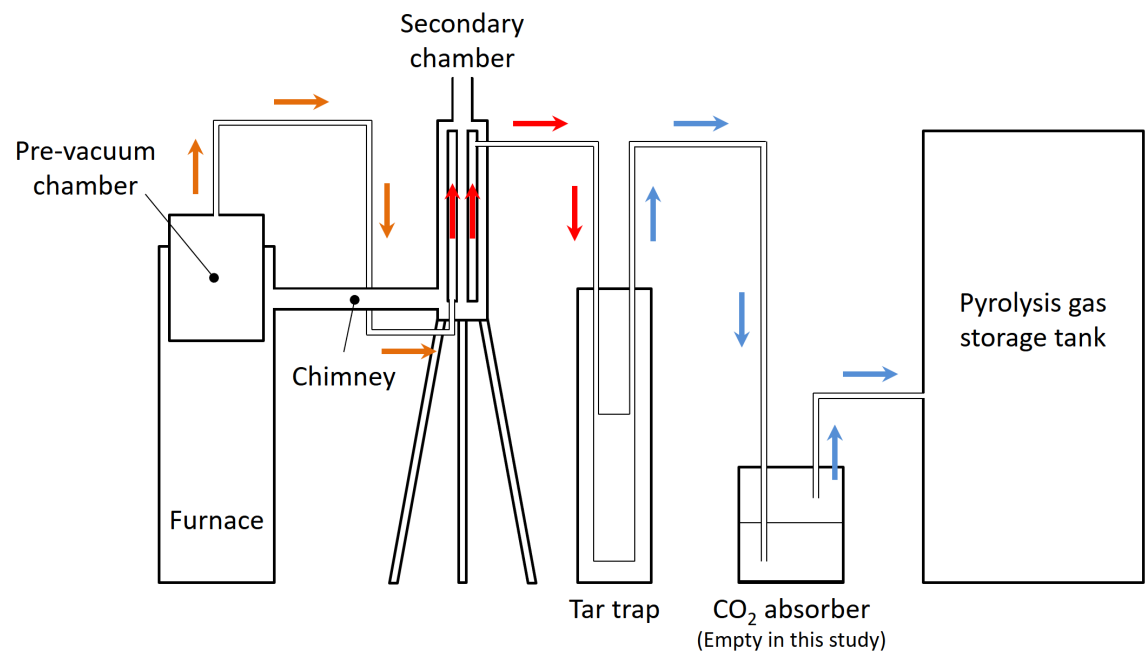

Figure 1. Schematic diagram of experimental apparatus. 
Table 1. Experimental conditons.

\begin{tabular}{cccc}
\hline Experiment description & $\begin{array}{c}\text { No } \\
\text { tar cracking }\end{array}$ & $\begin{array}{c}\text { Homogeneous } \\
\text { tar cracking }\end{array}$ & $\begin{array}{c}\text { Heterogeneous } \\
\text { tar cracking }\end{array}$ \\
\hline Feedstock [kg] & 1.0 & 1.0 & 1.0 \\
Char [g] & 0.0 & 0.0 & 40.0 \\
Pressure [MPa] & 0.3 & 0.3 & 0.3 \\
\hline
\end{tabular}

wastes supplied by a furniture company in Medan Indonesia. To keep humidity of feedstock constant, wood pieces are placed in a dry box having humidity absorbent, calcium chloride for one week before experiment. Two kg of wood pieces are kept in the dry box having $270 \mathrm{~g}$ of calcium chloride. Calcium chloride can absorb water twice as heavy as weight of calcium chloride. The wood pieces are dried to around $10 \%$ of humidity. Tar is recovered as liquid matter in the tar trap. If the feedstock contains much humidity, liquid matter, namely tar is recovered reflecting the humidity. Therefore, humidity of feedstock must be kept constant as accurately as possible to discuss experimental results reasonably.

Feedstock loaded in the pre-vacuum chamber is $1 \mathrm{~kg}$ for all the experimental conditions as shown in Table 1. In the experiment for heterogeneous tar cracking, $80 \mathrm{~g}$ of char is used for catalyst, which is produced by the previous experiment and to which any special treatment is not applied.

\subsubsection{Secondary Tar Cracking}

When feedstock undergoes pyrolysis process, gases including tar vapor are emitted from the feedstock and fill the pre-vacuum chamber and the secondary chamber that are initially evacuated to vacuum. As the pyrolysis process progresses and gases fill the chambers, pressure in the chambers increases. Because valve is fit to piping before the tar trap and shut, gas flow is stationary in the chambers until the valve is opened. The valve is opened when the pressure reaches $0.3 \mathrm{MPa}$. Therefore, pyrolysis gases including tar vapor are heated up in the secondary chamber. Although precise temperature control is almost impossible, a conventional wood stove is used for a furnace, because the stove is one of the most popular and suitable furnaces in rural area where maintenance service is not frequently available. Nevertheless, possibility of gas yield enhancement by means of secondary tar cracking should be investigated for rural area people, who cannot access electricity. One key skill is to keep exhaust gas up to $700^{\circ} \mathrm{C}$. Several feeding ways of fuel wood pieces with the stove were tried and the best way is found. It is to keep solid burning of wood as long as possible. However, when a stove charge port is opened at every feeding time, the exhaust gas temperature is down.

When the pressure reaches $0.3 \mathrm{MPa}$, the valve is opened and valve opening is adjusted to keep the pressure constant, $0.3 \mathrm{MPa}$. This operation is taken so that gas yield including tar vapor stay in the secondary chamber as long as possible. 


\section{Experimental Result and Discussion}

\subsection{Temperatures at Bottom of Pre-Vacuum Chamber and Exhaust Gas}

During experiments, temperatures at bottom of pre-vacuum chamber and exhaust gas are monitored using sheathe type of thermos-couples. The measured results are plotted as a function of time in Figure 2.

Experiments were carried out three times every condition. In the figure, average temperature is plotted. As mentioned above, averaged temperature of exhaust gas is still fluctuated with time. Nevertheless, temperature at the pre-vacuum chamber bottom is rather smooth as compared with exhaust gas temperature. In Figure 2(a), temperature-time histories at the pre-vacuum chamber are plotted for three experimental conditions, namely, reference experiment without a secondary chamber, experiment of homogeneous tar cracking with a secondary chamber, and experiment of heterogeneous tar cracking with a secondary chamber equipped with a char box filled with $80 \mathrm{~g}$ of char. No significant difference between them is seen. The temperature smoothly increases with time to $20 \mathrm{mi}$ nutes. In experiment 1 and 2, temperature fluctuates and increases with time. The fluctuation may result from pyrolysis progress in the pre-vacuum chamber. Primary decomposition of lignin and xylan (hemicellulose) starts at $200^{\circ} \mathrm{C}$, and $230^{\circ} \mathrm{C}$, respectively, while primary cellulose decomposition takes place in a narrow temperature range between $330^{\circ} \mathrm{C}$ and $400^{\circ} \mathrm{C}$ [22]. Pyrolysis process is well known as an endothermal reaction. Therefore, pyrolysis reaction causes temperature drop. The first temperature fluctuation at $150^{\circ} \mathrm{C}$ to $200^{\circ} \mathrm{C}$ may correspond to hemicellulose and lignin decomposition. The pyrolysis completion is defined as the condition where the pressure in the pre-vacuum chamber does not lift beyond 0.3 MPa for more than 5 minutes. According to this definition, for all the experimental conditions, pyrolysis of $1 \mathrm{~kg}$ rubber wood pieces terminates in 60 to 70 minutes. It should be noted that temperature at bottom of pre-vacuum chamber has a similar time history for three experimental conditions.

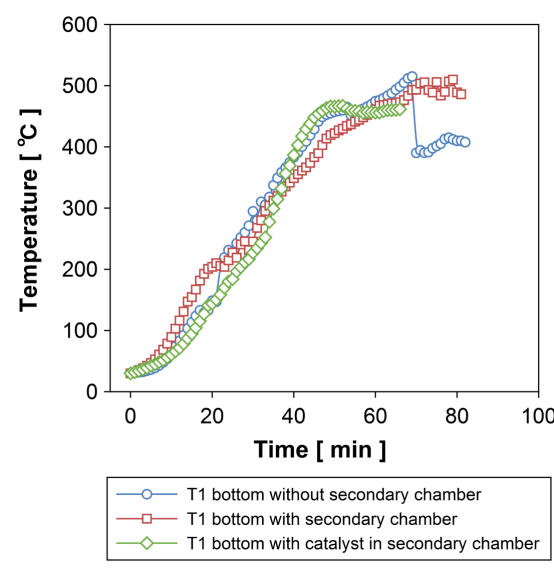

(a)

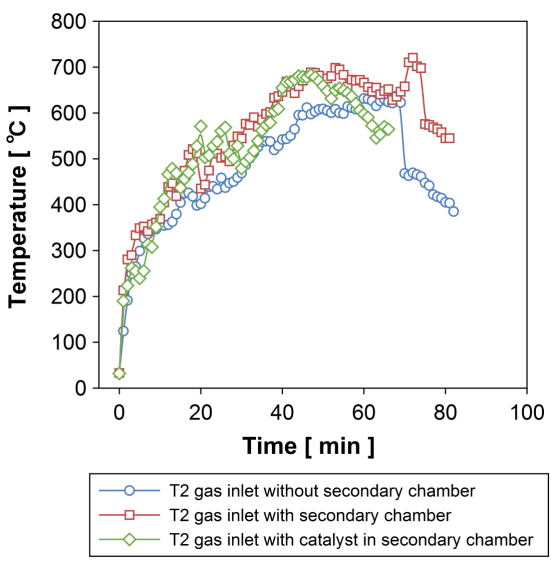

(b)

Figure 2. Temperature-time histories for three experimental conditions. (a) Temperature-time histories at bottom of pre-vacuum chamber; (b) Temperature-time histories before inlet of secondary chamber. 
On the other hand, temperature of exhaust gas from a wood stove steeply increases to $300^{\circ} \mathrm{C}$ and then moderately increases to $500^{\circ} \mathrm{C}$ taking 20 to 30 minutes. In experiments of homogeneous tar cracking and heterogeneous tar cracking, exhaust gas temperature reaches $600^{\circ} \mathrm{C}$ after 40 minutes and then, keep more than $600^{\circ} \mathrm{C}$ for 10 to 20 minutes. It can be expected that secondary tar cracking surely takes place in the secondary chamber, if pyrolysis gases are effectively heated by this hot exhaust gas. Large fluctuation in temperature of exhaust gas results from cold air suction into the wood stove at the time of fuel feeding.

Measurement of pyrolysis gas temperature in the secondary chamber is technically difficult. The secondary chamber is placed in a large chimney and is initially evacuated into vacuum, and then, the secondary chamber is taken out of the chimney after experiment for char charging. If a sheathe type of thermo-couple is used to monitor pyrolysis gas temperature in the secondary chamber, to keep sealing for vacuum and to disassemble the secondary chamber fitted with the thermocouple requires a lot of patience and skill. Therefore, to avoid such patience and experimental skill, numerical analysis is used to monitor the pyrolysis gas temperature in the secondary chamber.

\subsection{Numerical Analysis on Temperature of Pyrolysis Gas in Secondary Chamber}

Using temperature data measured by experiments, heat and mass analysis is carried out using ANSYS Fluent ver.13. A half of cross section of the secondary chamber shown in Figure 3 is modelled for numerical analysis. The numerical

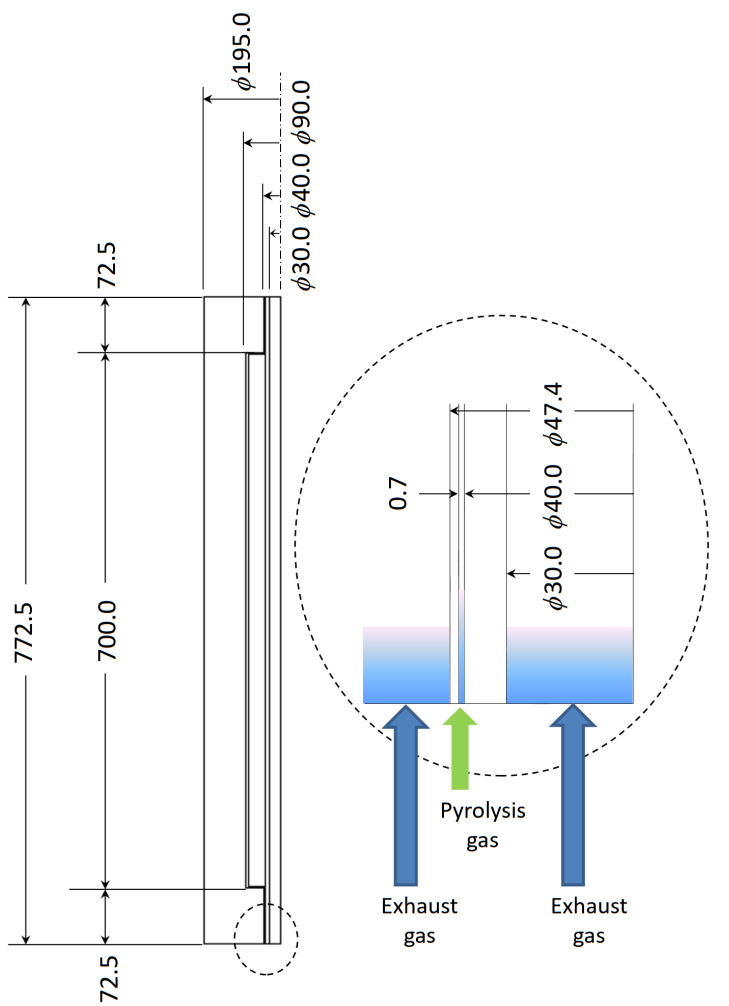

Figure 3. Numerical analysis model of secondary chamber. 
model is the same in dimensions as an actual secondary chamber, while inlets and outlets of the secondary chamber for exhaust gas and pyrolysis gas are modified to axi-symmetric configuration for simple numerical calculation. At the right hand of Figure 3, the inlet parts are enlarged to illustrate flow of pyrolysis gases and exhaust gas into the secondary chamber with arrows. Those gases flow into the secondary chamber from the bottom through cylindrical inlets for an axi-symmetric problem.

This simplification for the axi-symmetry will not bring about significant error in numerical result. The exhaust gas temperature at the inlet is specified by the result measured in the experiment shown in Figure 2(b). The pyrolysis gas temperature at the inlet is given by the result measured in the previous experiment [16]. Outermost surface of the secondary chamber is wrapped by rock wool tape for thermal insulation. Numerical analysis treats the thermal insulation as follows:

1) Perfect thermal insulation. Namely, the outermost surface of the secondary chamber is thermally insulated.

2) Insulation performance of the rock wool tape is not perfect, thus, heat is released from the outer surface. The heat flux density $q$ is defined as

$$
\begin{gathered}
q=K\left(T_{\text {os }}-T_{\text {air }}\right) \\
\frac{1}{K}=\frac{\delta_{\text {is }}}{\lambda}+\frac{1}{h_{\text {air }}}=\frac{0.005}{0.04}+\frac{1}{5}=0.325
\end{gathered}
$$

where $K$ is heat transmission coefficient, $T_{o s}$ is outer surface temperature, $T_{\text {air }}$ is air temperature, $\delta_{i s}$ is insulation tape thickness, $\lambda$ is thermal conduction coefficient, and $h_{\text {air }}$ is heat transfer coefficient of air.

Temperature distribution inside the secondary chamber is shown for the time of $1552 \mathrm{sec}$ in Figure 4. The exhaust gas and the pyrolysis gas enter the inlets located at the left hand side and exit the outlets at the right hand side in the

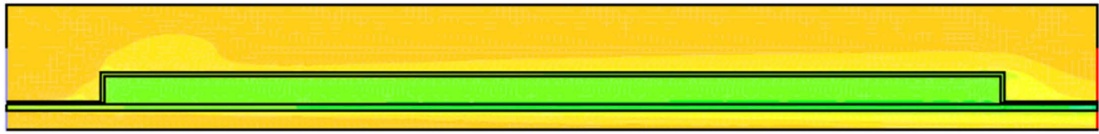

(a)

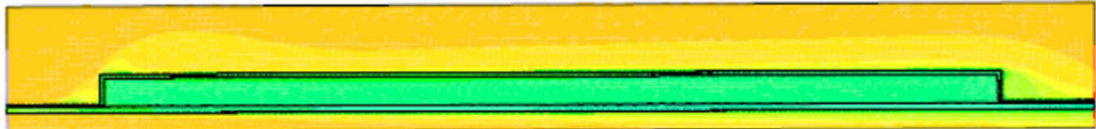

(b)

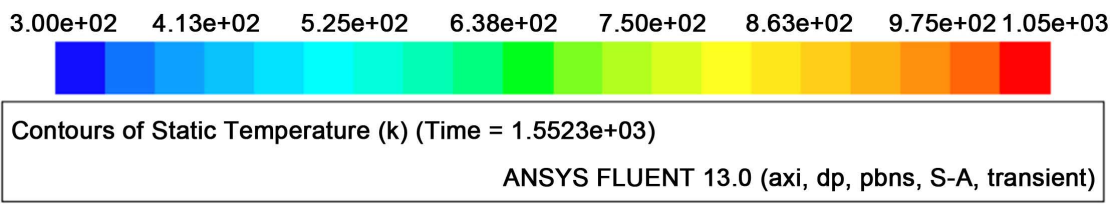

Figure 4. Comparison of temperature distributions for different boundary conditions at the outermost wall. (a) Outer wall is completely insulated; (b) Heat flux is allowed from outer wall. 
figure. In Figure 4(a), the result is shown for case where the outermost wall is thermally insulated, and in Figure 4(b), the result is shown for case where heat flux is allowed from the outermost wall to ambient air according to Equations (1) and (2). It is seen from the figure that the temperature of the pyrolysis gas is lower in case of heat flux allowance than one in case of thermal insulation. Heat flux allowed from the outermost wall can be considered more realistic as compared with complete thermal insulation. Therefore, pyrolysis gas temperature in case of heat flux allowance is examined in detail. In Figure 5, pyrolysis gas temperatures near inner wall and at the center of the middle tube, pyrolysis gas pass are plotted as a function of time. In the figure, exhaust gas temperature is also plotted for the reference. The exhaust gas temperature rises to $430^{\circ} \mathrm{C}(700 \mathrm{~K})$ steeply in first 10 minutes, while pyrolysis gas is not heated up remarkably and the temperature of the pyrolysis gas remains at low level. Pyrolysis gas is heated gradually in the pre-vacuum chamber and is led to the secondary chamber. The exhaust gas is also heated up to $660^{\circ} \mathrm{C}(930 \mathrm{~K})$ at time of 30 minutes. Pressure of the secondary chamber reaches $0.3 \mathrm{MPa}$ at 27 to 30 minutes. Then, the pressure is kept $0.3 \mathrm{MPa}$ by adjusting open angle of the valve until the end of the experiment. Then, the pyrolysis gas flows out from the secondary chamber to the tar trap. When the valve opens and the pyrolysis gas flows out from the secondary chamber, the pyrolysis gas temperature reaches $670 \mathrm{~K}\left(400^{\circ} \mathrm{C}\right)$ and rises up to $870 \mathrm{~K}\left(600^{\circ} \mathrm{C}\right)$ at the end of the experiment, $3600 \mathrm{sec}$. There is no significant difference between temperatures of the pyrolysis gas at two positions, and it is in range of 5 and $10 \mathrm{~K}$. The pyrolysis gas temperature smoothly rises over the experimental period, while the exhaust gas temperature fluctuates remarkably.

In Figure 5, for reference, pyrolysis gas temperature in case of perfect insulation of outermost wall is also shown with a dotted line. Pyrolysis gas temperature is around $100 \mathrm{~K}$ higher in the perfect insulation case than in case of heat flux allowance.

\subsection{Pyrolysis Yields and Compositions of Gas Yield}

For three experimental conditions, pyrolysis yields are measured after experiments

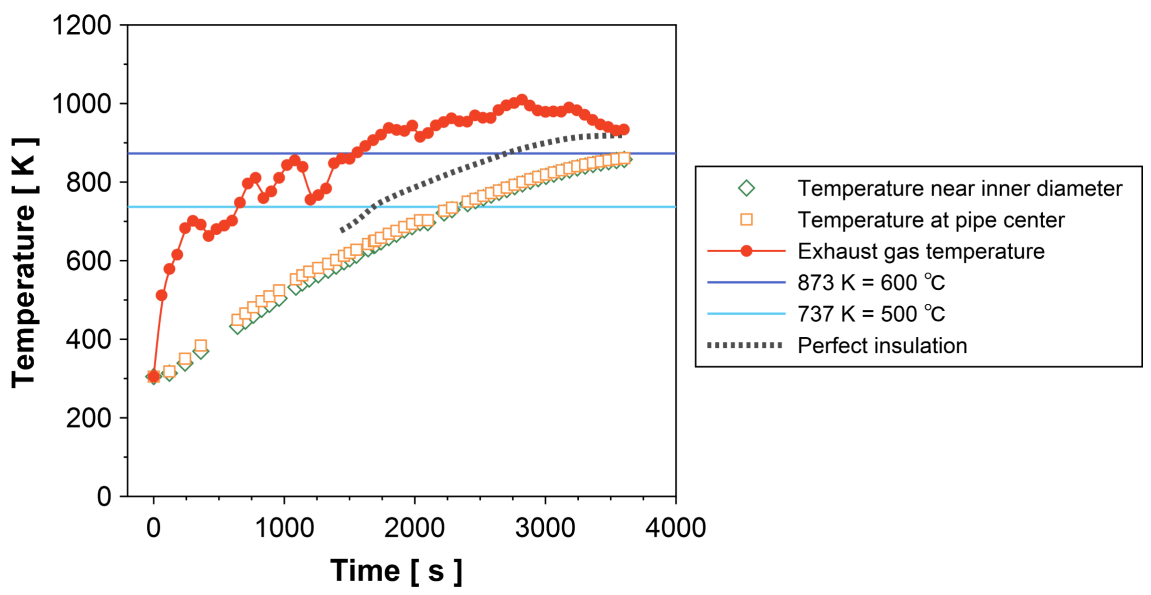

Figure 5. Temperature-time history of the pyrolysis gas in the secondary chamber. 
and measured results are summarized in Table 2. Experiment without a secondary chamber produced tar of $0.44 \mathrm{~kg}$, char of $0.29 \mathrm{~kg}$ and gas of $0.23 \mathrm{~kg}$ as shown in the first row. Results of experiment aiming at homogeneous tar cracking are shown in the second row. Comparison between the two results indicates no significant difference between them and suggests that there is no clear evidence of secondary tar cracking. According to numerical analysis result on temperaturetime history in the secondary chamber, if the wall surface of the secondary chamber is perfectly insulated thermally to the ambient air, pyrolysis gas is heated up to more than $900 \mathrm{~K}\left(627^{\circ} \mathrm{C}\right)$. Therefore, the secondary tar cracking likely takes place. However, the pyrolysis yields provide negative evidence for the homogeneous secondary tar cracking. On the other hand, if heat flux from the outermost wall of the secondary chamber is allowed instead of the perfect thermal insulation, the pyrolysis gas temperature can reach $600^{\circ} \mathrm{C}$ at the end of the experiment. It is quite unlikely that homogeneous secondary tar cracking takes place in the secondary chamber.

When $80 \mathrm{~g}$ of char was inserted in the secondary chamber, tar yield was decreased from $0.44 \mathrm{~g}$ to $0.37 \mathrm{~g}$. One-way analysis of variance using F-distribution suggests that there is significant difference in tar yields by pyrolysis without secondary chamber and with secondary chamber containing char. This may suggest that secondary tar cracking took place in the secondary chamber. It is likely that char can function as a catalyst for secondary tar cracking and the secondary tar cracking takes place under temperature of lower than $600^{\circ} \mathrm{C}$, like $500^{\circ} \mathrm{C}$. Analysis results of pyrolysis gas component by gas chromatography are shown in Table 3. The table compares results for pyrolysis gas produced by the secondary chamber without catalyst, char and pyrolysis gas produced by the secondary chamber with catalyst, char. Existence of char increases $\mathrm{H}_{2}, \mathrm{CH}_{4}, \mathrm{CO}$ components and decreases $\mathrm{CO}_{2}$ component. As mentioned by the previous researcher [21], char surely functions as a catalyst, and cracking temperature of

Table 2. Pyrolysis yields obtained by three experimental conditions.

\begin{tabular}{ccccccccc}
\hline \multirow{2}{*}{ Experiments } & Feedstock & \multicolumn{2}{c}{ Tar } & \multicolumn{2}{c}{ Char } & \multicolumn{2}{c}{ Gas } \\
\cline { 2 - 9 } & $\mathrm{kg}$ & $\mathrm{kg}$ & $\%$ & $\mathrm{~kg}$ & $\%$ & $\mathrm{~kg}$ & $\%$ \\
\hline Without secondary chamber & 0.98 & 0.44 & 45.5 & 0.29 & 30.4 & 0.23 & 24.1 \\
With secondary chamber & 0.97 & 0.41 & 42.3 & 0.30 & 31.7 & 0.25 & 26.0 \\
With secondary chamber + char & 0.96 & 0.37 & 38.9 & 0.30 & 31.4 & 0.28 & 29.7
\end{tabular}

Note: Percentages shown in tar, char, and gas columns represent weight $\%$ to feedstock.

Table 3. Gas component wt $\%$.

\begin{tabular}{ccc}
\hline Gas component & Without char & With char \\
\hline $\mathrm{H}_{2}$ & 26.4 & 28.5 \\
$\mathrm{CH}_{4}$ & 10.7 & 18.4 \\
$\mathrm{CO}$ & 20.0 & 21.4 \\
$\mathrm{CO}_{2}$ & 43.0 & 31.6 \\
\hline
\end{tabular}


primary tar can be downed by around $100^{\circ} \mathrm{C}$. The results shown in Table 2 and Table 3 provide evidences of secondary tar cracking. However, amount of secondary tar cracking is not large as expected.

\section{Conclusions}

In order to enhance efficiency of a simple and less maintained proto-type plant of biomass pyrolysis that can be used for a family living in rural areas where they cannot access electricity, concept of secondary tar cracking is introduced into the proto-type plant. A secondary chamber for the secondary tar cracking is designed and installed with the proto-type plant. The secondary chamber aims to heat up pyrolysis gas to temperature for the secondary tar cracking with and without a catalyst, char. The conclusions obtained from the experiments and numerical analysis of heat and mass transfer are as follows:

1) Pyrolysis gas produced in pre-vacuum chamber is surely heated up to the temperature for the homogeneous tar cracking in the secondary chamber. However, tar yield does not decrease significantly as compared with the reference result without the secondary chamber.

2) Numerical analysis of heat and mass transfer in the secondary chamber shows that the pyrolysis gas is heated up to more than $600^{\circ} \mathrm{C}$, under which the secondary tar cracking can take place. It suggests that the secondary tar cracking may take place at higher temperature than one reached by the experiment.

3) The secondary tar cracking surely take place in the secondary chamber when $80 \mathrm{~g}$ of char is used for a catalyst. It can be understood that the secondary tar cracking take place at low temperature by existence of catalyst, char.

4) Char surely works as a catalyst for secondary tar cracking, but amount of cracked tar is not as large as expected. To obtain higher performance of the proto-type plant, further investigation is necessary.

\section{Acknowledgements}

The authors express their gratitude toward Mr. Kosasih Matseh, PT Salix Bintama Prima for his useful advices and provision of feedstock used in experiments.

\section{References}

[1] United Nations Framework Congress on Climate Change (2015) Conference of the Parties 21st Session. UNFCC/CP/2015/L.9Annex, Paris, 30 November-11 December 2015, 22.

[2] International Energy Agency (2016) Decoupling of Global Emissions and Economic Growth Confirmed. Press Release 2016.

https://www.iea.org/newsroom/news/2016/march/decoupling-of-global-emissions-a nd-economic-growth-confirmed.html

[3] International Energy Agency (2015) Southeast Asia Energy Outlook 2015. IEA Publications, Paris.

[4] Homma, H., Homma, H., Yusrizal and Idris, M. (2013) Wood Pyrolysis in PreVacuum Chamber. Journal of Sustainable Bioenergy Systems, 3, 243-249.

https://doi.org/10.4236/jsbs.2013.34033 
[5] Homma, H., Homma, H. and Idris, M. (2014) Numerical Analysis on Wood Pyrolysis in Pre-Vacuum Chamber. Journal of Sustainable Bioenergy Systems, 4, 145 160. https://doi.org/10.4236/jsbs.2014.43014

[6] Jahirul, M.I., Rasul, M.G., Chowdhury, A.A. and Ashwath, N. (2012) Biofuels Production through Biomass Pyrolysis-A Technological Review. Energies, 5, 4952 5001. https://doi.org/10.3390/en5124952

[7] Fagbemi, L., Khezami, L. and Capart, R. (2001) Pyrolysis Products from Different Biomasses: Application to the Thermal Cracking of Tar. Applied Energy, 69, 293306. https://doi.org/10.1016/S0306-2619(01)00013-7

[8] Dufour, A., Girods, P., Masson, E., Rogaume, Y. and Zoulalian, A. (2009) Synthesis Gas Production by Biomass Pyrolysis: Effect of Reactor Temperature on Product Distribution. International Journal of Hydrogen Energy, 34, 1726-1734.

https://doi.org/10.1016/j.ijhydene.2008.11.075

[9] Boroson, M.L., Howard, J.B., Longwell, J.P. and Peters, W.A. (1987) Effects of Extra-Particle Secondary Reactions of Fresh Tars on Liquids Yields in Hardwood Pyrolysis. Proceedings of the 193rd American Chemical Society National Meeting, Denver, 5-10 April 1987, 51-58.

[10] Rath, J. and Staudinger, G. (2001) Cracking Reactions of Tar from Pyrolysis of Spruce Wood. Fuel, 80, 1379-1389. https://doi.org/10.1016/S0016-2361(01)00016-3

[11] Morf, P.O. (2001) Secondary Reactions of Tar during Thermochemical Biomass Conversion. Ph.D. Thesis, Swiss Federal Institute of Technology in Zurich, Zurich.

[12] Morf, P., Hasler, P. and Nussbaumer, T. (2002) Mechanisms and Kinetics of Homogeneous Secondary Reactions of Tar from Continuous Pyrolysis of Wood Chips. Fuel, 81, 843-853. https://doi.org/10.1016/S0016-2361(01)00216-2

[13] Milne, T.A., Evans, R.J. and Abatzoglou, N. (1998) Biomass Gasifier "Tars": Their Nature, Formation and Conversion. National Renewable Energy Laboratory, NREL/ TP-570-25357, Golden.

[14] Vreugdenhil, B.J. and Zwart, R.W.R. (2009) Tar Formation in Pyrolysis and Gasification. Energy Research Center of the Netherlands, ECN-E--08-087, Petten.

[15] Elfasakhany, A. (2012) Modeling of Secondary Reaction of Tar (SRT) Using a Functional Group Model. International Journal of Mechanical Engineering \& Technolo$g y, 3,123-136$.

[16] Nordgreen, T., Liliedahl, T. and Sjöström, K. (2006) Metallic Iron as a Tar Breakdown Catalyst Related to Atmospheric, Fluidised Bed Gasification of Biomass. Fuel, 85, 689-694. https://doi.org/10.1016/j.fuel.2005.08.026

[17] Laosiripojana, N., Sutthisripok, W., Charojrochkul, S. and Assabumrungrat, S. (2014) Development of Ni-Fe Bimetallic Based Catalysts for Biomass Tar Cracking/ Reforming: Effects of Catalyst Support and Co-Fed Reactants on Tar Conversion Characteristics. Fuel Processing Technology, 127, 26-32. https://doi.org/10.1016/j.fuproc.2014.06.015

[18] James, A.M., Yuan, W., Boyette, M.D., Wang, D. and Kumar, A. (2014) In-Chamber Thermocatalytic Tar Cracking and Syngas Reforming Using Char-Supported NiO Catalyst in an Updraft Biomass Gasifier. International Journal of Agricultural and Biological Engineering, 7, 91-97. https://doi.org/10.3390/en4081163

[19] Huang, J., Schmidt, K.G. and Bian, Z. (2011) Removal and Conversion of Tar in Syngas from Woody Biomass Gasification for Power Utilization Using Catalytic Hydrocracking. Energies, 4, 1163-1177.

[20] Mihalcik, D.J., Mullen, C.A. and Boateng, A.A. (2011) Screening Acidic Zeolites for Catalytic Fast Pyrolysis of Biomass and Its Components. Journal of Analytical and 
Applied Pyrolysis, 92, 224-232. https://doi.org/10.1016/j.jaap.2011.06.001

[21] Klinghoffer, N. (2013) Utilization of Char from Biomass Gasification in Catalytic Application. Ph.D. Thesis, Columbia University, New York.

[22] Giudicianni, P., Cardone, G. and Ragucci, R. (2013) Cellulose, Hemicellulose and Lignin Slow Steam Pyrolysis: Thermal Decomposition of Biomass Components Mixtures. Journal of Analytical and Applied Pyrolysis, 100, 213-222.

https://doi.org/10.1016/j.jaap.2012.12.026

Submit or recommend next manuscript to SCIRP and we will provide best service for you:

Accepting pre-submission inquiries through Email, Facebook, LinkedIn, Twitter, etc. A wide selection of journals (inclusive of 9 subjects, more than 200 journals)

Providing 24-hour high-quality service

User-friendly online submission system

Fair and swift peer-review system

Efficient typesetting and proofreading procedure

Display of the result of downloads and visits, as well as the number of cited articles

Maximum dissemination of your research work

Submit your manuscript at: http://papersubmission.scirp.org/

Or contact jsbs@scirp.org 